\title{
Realitas Pesantren dan Kebijakan Pendidikan Islam dalam Perspektif Hegemoni Antonio Gramsci
}

\author{
Nur Jannah \\ ${ }^{1}$ Institut Agama Islam Al-Falah As-Sunniyah Kencong
}

\author{
Keywords: \\ Pesantren, \\ Hegemony, Antonio Gramsci \\ Kata Kunci: \\ Pesantren, \\ Hegemoni, Antonio Gramsci
}

*Correspondence Address: nurjannah@inaifas.ac.id

\begin{abstract}
The significance of this paper seeks to conceptualize the hegemony process in the establishment of Islamic boarding school education policies in Indonesia and the elites role within (organic intellectuals) as a counter-hegemonic group for those who have any interest in government. This paper was raised to contribute thoughts related to the concept of the politics of Islamic education policy, hegemony and counter hegemony in Islamic education policy so that it can be investigated and developed in a more comprehensive and holistic direction. Antonio Gramsci's perspective of hegemony is used to analyze what happens in the process of policy emergence. Using a descriptive qualitative method with the main instrument of documentation, the authors identify a series of compromising hegemony and counter hegemony between the government and Islamic education institution. Although this compromise model is not considered to be a new way in determining policy, the compromise model adopted is more radical because the government gives broad freedom to the forms and models of the islamic educational system.
\end{abstract}

\begin{abstract}
Abstrak: Sigfinifikansi tulisan ini berupaya untuk mengkonseptualisasi proses hegemoni dalam penetapan kebijakan pendidikan pesantren di Indonesia dan peran elit pesantren (intelektual organik) sebagai suatu kelompok yang kontra hegemonik terhadap kelompok kepentingan dalam tubuh pemerintahan. Tulisan ini diangkat untuk memberikan sumbangan pemikiran terkait konsep mengenai politik kebijakan pendidikan Islam, hegemoni dan kontra hegemoni dalam kebijakan pendidikan Islam agar dapat dikaji dan dikembangkan ke arah yang lebih komprehensif dan holisitik. Perspektif Hegemoni dari Antonio Gramsci dipakai untuk menganalisis apa ayang terjadi dalam proses munculnya kebijakan. Menggunakan metode kualitatif deskriptif dengan instrumen utama dokumentasi, penulis melihat telah terjadi rangkaian hegemoni dan kontra hegemoni yang kompromistik antara pemerintah dan pesantren. Meskipun model kompromistik ini bukan hal baru dalam penetapan kebijakan, namun model kompromi yang dianut lebih cenderung radikal karena pemerintah memberikan kebebasan yang luas terhadap bentuk maupun model sistem pendidikan pesantren.
\end{abstract}

\section{Pendahuluan}

Secara historis sebelum datangnya Islam ke Indonesia lembaga serupa pesantren sudah ada. Umat Islam kemudian meneruskan, melestarikan dan mengislamkannya. Bisa dikatakan bahwa pesantren adalah bagian dari hasil penyerapan akulturasi kebudayaan Hindu-Budha dan kebudayaan Islam itu sendiri. Tidak heran bila pesantren sangat identik dengan makna keislaman tetapi juga 
$\begin{array}{ccc}\text { mengandung } & \text { makna } & \text { keaslian } \\ \text { (indigenous) } & \text { Indonesia. } 1 & \text { Sejarah }\end{array}$ pesantren unik karena terkait dengan nilai-nilai sosial yang amat tua dan model-modelnya terhadap respon sosial masyarakat pribumi terhadap budaya lain. ${ }^{2}$

Pada masa kerajaan-kerajaan Islam Nusantara, pesantren ${ }^{3}$ berdiri di pusat-pusat kekuasaan dan menjadi satu-satunya sistem pendidikan yang berfungsi sebagai lembaga kaderisasi bagi para putera pembesar kerajaan. ${ }^{4}$ Namun sejak masa kolonial, melalui stigmatisasi negatif dan propaganda penguasa kolonial, pesantren menjauh dari pusat kekuasaan. Sejarah mencatat bahwa sikap non-kooperatif dan silent opposition ulama terhadap kebijakan "politik etis" pemerintah kolonial Belanda pada akhir abad ke 19 menjadikan pesantren berkembang

${ }^{1}$ Nurcholish Madjid, Bilik-Bilik Pesantren: Sebuah Potret Perjalanan, Cet. 1 (Jakarta : Paramadina, 1997), 3. Lihat Akhtim Wahyuni. Peran Sosial Pesantren dalam Pemberdayaan masyarakat. Jurnal Ilmiah Kreatif Vol. VI no. 1 Januari (2009): 27

2 Salah satu gambaran sisa pengaruh asimilasi tersebut tampak pada proses penyebaran Islam yang merupakan hasil perpaduan antara doktrin formal Islam dan kultus para wali yang sama dengan tradisi pemujaan orang-orang suci dalam agama hindu. Lihat Abdurrahman Wahid. Bunga Rampai Pesantren. (Jakarta: Dharma Bhakti, 1984), 17.

3 Sebagai lembaga pendidikan Islam tertua di Indonesia Pesantren tumbuh bersamaan dengan masa penyebaran Agama Islam di nusantara, yang kuat diduga penyebaran itu dimulai sejak abad ke-7 Masehi oleh para musafir dan pedagang Muslim, melalui jalur perdagangan dari teluk persia dan Tiongkok. Mengenai kapan, di mana dan oleh siapa pesantren pertama kali didirikan sulit dilacak karena keterbatasan bukti sejarah maupun literatur mengenai hal itu. Lihat Mastuhu. Dinamika Sistem Pendidikan Pesantren (Jakarta: INIS, 1994) 19-20, bandingkan dengan Martin Van Bruinessen. Kitab Kuning, Pesantren dan Tarekat: Tradisi-tradisi Islam di Indonesia. (Jakarta: Mizan. 1995), 20-26, dan Kareel A. pesat secara khas di tengah-tengah masyarakat pedalaman ${ }^{5}$ sekaligus menjadikannya terisolasi dari persoalan politik serta kurang diperhatikan eksistensinya secara nasional.

Untuk itu pada mulanya fokus pesantren bergerak di bidang dakwah dan pendidikan, independen dari atmosfir politik. Namun karena gesekan serta intervensi politik menjangkau segenap jalur kehidupan sosial masyarakat, tidak terkecuali ulama dengan Islam politiknya dan pesantren dengan kekuatan massanya, kekuasaan pemerintah secara hegemonis memaksa orientasi pesantren berubah. Sebagian ulama terjun ke dalam politik praktis. Pesantren menjadi termobilisasi dalam rangka menarik massa demi kepentingan penguasa agar berada dalam spektrum kebijakan dan kekuasaan pemerintah. ${ }^{6}$

Steenbrink. Madrasah, Pesantren, Sekolah: Pendidikan Islam dalam Kurun Modern. (Jakarta: LP3ES. 1986), 20-23 Lihat juga Abdurrahman Mas'ud, Sejarah dan Budaya Pesantren. Dalam Ismail SM (ed) Dinamika Pesantren dan Madrasah (Yogyakarta: Pustaka Pelajar), 2002, 18-19

4 Mohammad Tidjani Djauhari. Masa Depan Pesantren Agenda yang belum Terselesaikan. (Jakarta: Taj Publishing. 2008), 79

5 Lihat Sulthon Masyhud. Manajemen Pondok Pesantren (Jakarta: Diva Pustaka, 2003), 1-2

6 Mobilisasi dipahami sebagai pengakomodasian kepentingan pesantren demi mendukung rekayasa pembangunan pemerintah. Ali Riyadi. Politik Pendidikan, Menggugat Birokrasi Pendidikan Nasional. Cet. 1 (Yogyakarta: Ar Ruzz. 2006), 193-195. Lihat Sudirman Tebba, Dilema Pesantren: Belenggu Politik dan Pembaruan Sosial, dalam Dawam Raharjo (ed), Pergulatan Dunia Pesantren: Membangun dari Bawah (Jakarta: P3M, 1985), 277. Baca juga Muhammad Asfar, Pergeseran Otoritas Kepemimpinan Politik Kiai, dalam Prisma, 5 Mei 1995), 31, Fathol Halik, Pendidikan Pesantren di Tengah Politisasi dan Globalisasi: Pesantren Madura Setelah Keruntuhan Orde Baru, dalam 
Pada masa pemerintahan orde baru hegemoni dalam kebijakan pendidikan keagamaan dilakukan dengan rekayasa politik melalui penataan sistem pendidikan atas dasar narasi modernisasi pendidikan ala Barat. ${ }^{7}$ Hal tersebut secara langsung maupun tidak berimplikasi terhadap rekognisi output pondok pesantren secara formal di lembaga-lembaga pemerintah dengan tidak berlakunya ijazah pesantren. Sebagai reaksi atas kebijakan tersebut beberapa pesantren lambat laun mulai beradaptasi terhadap kebijakan pemerintah. Ada pesantren yang merevisi kurikulum dan menyesuaikan sistem belajar mengajar sesuai kebijakan pemerintah serta membuka kelembagaan dan fasilitas kependidikan umum. ${ }^{8}$ Tetapi sebagian yang lain tetap bertahan dalam sistem pendidikan khas pesantren, sambil berbenah melakukan transformaasi atas dasar rasionalitas dan kemajuan, tanpa meninggalkan prinsip trasionalnya "al muhâfadhah ála al qadîmis shâlih wa al akhdz bi al jadîdi al ashlah," (melestarikan yang lama tapi

KARSA Jurnal Ilmiah, Vol XV no. 1 April 2009,, 63-64.

${ }^{7}$ Azyumardi Azra. Pesantren: Kontinuitas dan Perubahan, dalam Nurcholish Madjid, Bilikbilik...h. xii

${ }^{8}$ Dalam hal ini para eksponen pesantren cenderung mempertahankan kebijakan lembaganya secara hati-hati. Lihat Ali Riyadi. Politik Pendidikan ...199-204. Lihat juga Kementerian Agama RI. 2010. Pedoman Pesantren Muadalah, 3 bandingkan dengan Affandi Mochtar dan Kusmana, Model Baru Pendidikan: Melanjutkan Modernisasi Pendidikan Islam di Indonesia, dalam Kusmana dan JM. Muslimin, Paradigma Baru Pendidikan Retrospeksi dan Proyeksi Modernisasi Pendidikan Islam di Indonesia, (Jakarta: IISEP, 2008), 20-24. Bandingkan juga dengan Abdurrahman Wahid, Menggerakkan Tradisi. Esai-esai Pesantren (Yogyakarta: LkiS, 2001), 35. Lihat Mujammil Qomar, Pesantren Dari Transformasi Metodologi Menuju Demokrasi Institusi, (Jakarta: Erlangga, 2006), 80-81 baik sekaligus mengadopsi yang baru yang lebih baik). ${ }^{9}$ Namun terkadang ada juga pesantren yang terjebak ke dalam praktik pendidikan yang ekslusif dan dogmatik, kurang menyentuh atau menyalahi aturan moralitas serta mementingkan kelompok sendiri. ${ }^{10}$

Terlepas dari hal itu, dalam perkembangannya pesantren memiliki banyak wajah (multifaces), selain sebagai penyelenggara pendidikan, ia juga berperan dalam masalah-masalah sosial lainnya. Pada masa pra kemerdekaan Pesantren telah berperan besar dalam melahirkan pejuangpejuang yang tangguh dalam memperjuangkan kemerdekaan. Setelah kemerdekaan Pondok Pesantren terus berperan dalam mencerdaskan kehidupan bangsa dan memberikan pelayanan sosial dalam menyiapkan tenaga-tenaga yang menguasai ilmu-ilmu keislaman sebagai kader ulama, muballigh atau Guru Agama yang sangat dibutuhkan oleh masyarakat, sekaligus turut pula mengimplementasikan "character building" bangsa Indonesia. ${ }^{11}$

9 Lihat Azyumardi Azra. Pesantren: Kointinuitas...h. 95-110

10 Lihat M. Amin Abdullah, Pengajaran Kalam dan Teologi di Era Kemajemukan: Sebuah Tinjauan Materi dan Metode Pendidikan Agama, dalam Tashwirul Afkar, Edisi no. 11 tahun 2001, 14. Bandingkan dengan Abdurrahman Mas'ud, Format Baru Pola Pendidikan Keagamaan pada Masyarakat Multikultural dalam Perspektif Sisdiknas, dalam Muammar Ramadhan dan Hesti Hardinah (ed), Antologi Studi Agama dan Pendidikan (Semarang: Aneka Ilmu, 2004), 8788, bandingkan dengan Kuntowijoyo, Muslim Tanpa Masjid (Bandung: Mizan), 2001, 27

11 Faisal Ismail, Percikan Pemikiran Islam, (Yogyakarta : Bina Usaha, 1984), 69. Lihat Abuddin Nata, Manajemen Pendidikan Mengatasi Kelemahan Pendidikan Islam di Indonesia (Jakarta: Kencana, 2003), 129-133, bandingkan dengan Moh Yamin, Menggugat Pendidikan Indonesia (Yogyakarta: Ar Ruzz Media, 2009), 99-103 
Realitas di atas menunjukkan bahwa negara telah melakukan berbagai upaya dalam menghegemoni masyarakat hingga menyentuh nilainilai dalam pendidikan keagamaan Islam yang sejatinya memiliki akar kuat di masyarakat. Hegemoni pemerintah dalam bidang kebijakan pendidikan keagamaan sebenarnya tidak menjadi masalah, kecuali jika kebijakan yang diambil dianggap mampu mengubah struktur maupun tatanan nilai luhur yang dibangun lembaga pendidikan kegamaan Islam. Oleh karenanya gerakan kontra hegemoni berperan penting dalam mengkounter hegemoni yang salah arah demi kepentingan bersama.

Dalam perspektif Antonio Gramsci, kontra hegemoni lahir dari kelompok-kelompok ataupun individu (intelektual organik) yang bertugas menyadarkan kembali akan eksistensi nilai luhur yang perlu dipertahankan maupun diubah demi kepentingan bersama. Dalam konteks tersebut lahir intelektual-intelektual organik dari pesantren yang menyadari bahwa kebijakan pendidikan keagamaan Islam di Indonesia belum mengakomodir kepentingan, nilai, ideologi dan tujuan pesantren itu sendiri. Salah satu poin yang menjadi problematika kebijakan pendidikan keagamaan Islam terkait pesantren adalah pengakuan formal ijazah yang mereka keluarkan.

Sigfinifikansi tulisan ini berupaya mengkonseptualisasi proses hegemoni dan kontra hegemoni dalam penetapan kebijakan pendidikan keagamaan Islam di Indonesia dan peran elit pesantren (intelektual organik) sebagai suatu kelompok yang kontra terhadap kelompok kepentingan dalam tubuh pemerintahan terkait penetapan kebijakan pendidikan keagamaan. Konseptualisasi ini penting dikemukakan dalam rangka memberikan sumbangsih pemikiran pada bidang kajian politik pendidikan yang masih jarang dibahas.

Secara praktis, kajian ini penting diangkat agar konsep-konsep mengenai politik kebijakan pendidikan, hegemoni dan kontra hegemoni mengenai kebijakn sistem pendidikan dapat dikaji dan dikembangkan oleh kelompokkelompok praksis pendidikan, segenap stakeholder pendidikan, maupun pemerintah dalam rangka mengembangkan ide, kritik dan masukan lainnya terkait dengan kebijakan pendidikan yang menyangkut kepentingan berbagai macam golongan. Apalagi bangsa ini adalah bangsa dengan identitas multikultural, sehingga dengan kebijakan yang seimbang mengenai pendidikan, utamanya pendidikan pesantren, maka bisa dipastikan tidak ada lagi lembagalembaga pendidikan di negeri ini yang dirugikan, dikucilkan, dan di 'anak tiri' kan apalagi hanya tinggal namanya saja.

\section{Tinjauan Hegemoni dan Kontra Hegemoni Gramsci}

a. Konteks Lahirnya Teori Hegemoni

Melihat permasalahan yang akan di bahas, seperti yang telah dijelaskan di atas, maka dalam studi ini digunakan teori hegemoni dan kontra hegemoni menurut perspektif Gramsci. Gagasannya tentang hegemoni tersebar dalam karyanya berbahasa Italia, Quaderni, yang kemudian diterbitkan dalam bahasa Inggris Selections From Prison Notebooks (disingkat SPN), yang dianggap sebagai karya yang bersifat sentral dalam kemunculan bentuk baru teori marxism, terutama di Italia sesudah perang dunia ke II.

Teori hegemoni Gramsci merupakan kritik terhadap konsep determinisme ekonomi dan dialektika sejarah Karl Max. Dalam kehidupan masyarakat, Marxisme meyakini bahwa basic (ekonomi) menentukan 
superstructure (ideologi, politik, pendidikan, budaya dan sebagainya). Lebih lanjut menurut dialektika sejarah Karl Marx, sistem kapitalisme akan menghasilkan kelas buruh dalam jumlah yang besar dan terjadi resesi ekonomi. Pada akhirnya, akan terjadi revolusi kaum buruh (proletar) yang akan melahirkan sistem sosialisme. Namun, revolusi itu tidak pernah terjadi, dan hal itu tidak dapat dijelaskan marxisme.

Selain itu Gramsci mendasarkan hegemoni pada ide Marx mengenai kesadaran palsu, suatu keadaan di mana individu-individu menjadi tidak sadar mengenai dominasi yang terjadi di dalam kehidupan mereka. Gramsci berpendapat bahwa khalayak dapat dieksploitasi oleh sistem sosial berupa ideologi yang diterima yang juga mereka dukung, mulai dari budaya popular; lagu-lagu pop, tarian atau dance, makanan, pendidikan, 12 hingga agama.

Menurut Gramsci, ideologi itulah sebenarnya sebagai basic yang menentukan superstructure, sehingga ketika revolusi kaum buruh (seperti anggapan Marxisme) tidak pernah terjadi, hal itu tidak bisa dijelaskan melalui konsep determinisme ekonomi Karl Max. Justru Gramsci berpendapat tidak adanya revolusi disebabkan oleh ideologi, nilai, kesadaran diri, dan organisasi kaum buruh tenggelam oleh hegemoni kaum penguasa. Dari sinilah kemudian Gramsci mengembangkan idenya mengenai hegemoni.

Istilah hegemoni pertama kali dipakai oleh Plekanov dan pengikut marxis Rusia lainnya pada tahun 1880

12 Pendidikan dijadikan sebagai salah satu alat indoktrinasi ideologi, bagi Gramsci pendidikan adalah alat fundamental dalam proses hegemoni. Carmel Borg, et.all. (ed) Gramsci and Education. Boston (Rowman \& Litlefield Publishers, 2002),8

13 Roger Simon. Gramsci's Political...h.24- untuk menunjukkan perlunya kelas pekerja untuk membangun aliansi dengan petani dengan tujuaan meruntuhkan gerakan Tsarisme. ${ }^{13}$ Istilah hegemoni itu sendiri berasal dari bahasa Yunani, egemonia, yang berarti penguasaan satu bangsa terhadap bangsa lain. ${ }^{14}$ Tetapi Gramsci memaknai hegemoni secara berbeda. Hegemoni bukan dominasi dalam arti represif, kekerasan, dan tekanan, tetapi ia adalah kepemimpinan moral, intelektual dan budaya berdasar konsensus. Menurut Gramsci, "hegemony is a relation, not of domination by means of force, but of consent by means of political and ideological leadership. It is the organisation of consent." 15 (Hegemoni bukanlah hubungan dominasi dengan menggunakan kekuasaan, melainkan hubungan persetujuan dengan menggunakan kepemimipinan politik dan ideologis. Ini tentang pengorganisasian konsensus).

Lebih lanjut Strinati menjelaskan, “...Dominant groups in society, including fundamentally but not exclusively the ruling class, maintain their dominance by securing the 'spontaneous consent' of subordinate groups, including the working class, through the negotiated construction of a political and ideological consensus which incorporates both dominant and dominated groups." 16

Secara sederhana, hegemoni merupakan dominasi oleh satu kelompok terhadap kelompok lainnya dengan menggunakan kesadaran ideologis, dengan atau tanpa ancaman kekerasan, sehingga ide-ide yang didiktekan oleh kelompok dominan terhadap kelompok yang

14 Roger Simon. Gramsci's Political Thought, an Introduction (London: Lawrence \& Wishart, 1982), 24, bandingkan dengan Dominic Strinati, An Introduction to Theories of Popular Culture, (London: Routledge, 1995), 124

15 Roger Simon, Gramsci's Political...h.24..

16 Dominic Strinati, An Introduction...h. 
didominasi diterima sebagai sesuatu yang wajar yang bersifat moral, intelektual serta budaya. Hegemoni bisa terjadi bukan hanya antara negara dengan negara lainnya, atau negara terhadap msayarakat, tetapi juga sebaliknya dan antar kelompok masyarakat itu sendiri. ${ }^{17}$

Hegemoni di tangan Gramsci, tidak semata dimaknai sebagai sebuah instrumen atau strategi dalam menjalankan revolusi, dan terutama dengan menjadikan negara sebagai titik akhirnya, melainkan "...sarana untuk memahami masyarakat dengan tujuan untuk mengubahnya." 18 Yang menjadi tema sentral dan yang sekaligus dibangun dalam hegemoni tidak melulu produksi kekuasaan, melainkan aliansi sosial-politik yang dipertemukan baik dengan menggunakan perjuangan politik maupun ideologis - bagaimana memperoleh persetujuan yang lahir secara sukarela, mandiri, rasional, dan partisipatif dari kelas-kelas lainnya. Tanpa menutup kemungkinan bahwa dalam setiap proses realisasinya sendiri, bentuk konsensus yang terjadi kerap kali diterapkan dengan mengedepankan tindak kekerasan. Inilah yang diartikulasikan oleh Gramsci sebagai metode persuasif (hegemoni) dan metode koersif (dominasi).

Hegemoni dengan demikian berbeda dengan dominasi. Hegemoni lebih melekat pada istilah konsensus sementara dominasi lebih cenderung ke arah makna kekerasan, pemaksaan, koersif, tekanan, sehingga dalam prakteknya dominasi dilakukan dengan segala cara bahkan bersifat fisik seperti penggunaan kekuatan militer.

Menurut Foucult, secara teoretis dikenal ada tiga bentuk hubungan, yaitu

17 Robert Gilpin, A Realist Perspective on International Governance, dalam David Held, Anthony McGrew (ed), Governing Globalization (Cambridge: Polity Press, 2004), 237 - 248, Raymond Williams, Keywords: A Vocabulary of dominasi, hegemoni, dan kooptasi. Dominasi dicirikan oleh adanya pihak yang didominasi dan yang mendominasi. Hegemoni adalah hubungan dengan basis intelektual dan moral yang dapat diterima oleh rakyat yang diperintah. Sementara itu, kooptasi merupakan suatu proses peneriman unsur-unsur baru dalam kepemimpinan atau praktek politik, sebagai salah satu cara untuk menghindari terjadinya kegoncangan dalam stabilitas organisasi yang bersangkutan. ${ }^{19}$

Meski dominasi dan hegemoni berbeda, kadang dominasi diperlukan oleh negara untuk mempertahankan hegemoninya, bahkan ia menjadi prasyarat suatu hegemoni. Menurut Gramsci semua kelas sosial di masyarakat memiliki kecenderungan untuk menghegemoni, ketika memiliki kemampuan untuk mendominasi. Dalam hal ini hegemoni bekerja dengan dua tahap yaitu tahap dominasi dan tahap direction atau pengarahan (hegemony). Siklus tersebut akan terus berlanjut. Jika sudah melalui tahapan dominasi maka tahap berikutnya yaitu tinggal diarahkan dan tunduk pada kepemimpinan oleh kelompok yang mendominasi. Siapa yang mencoba melawan hegemoni dianggap orang yang tidak paham dan tidak taat terhadap moral serta dianggap melanggar norma di masyarakat. Meski bahkan adakalanya diredam dengan kekerasan.

\section{b. Nasional Kerakyatan}

Terkait dengan hegemoni, Gramsci juga mengemukakan konsep tentang nasional kerakyatan. Suatu kelompok tidak bisa meraih

Culture and Society. Revised Edition, (New York: Oxford University Press, 1985), 144

18 Roger Simon, Gramsci's Political...h. 99

19 Michel Foucult. Power/Knowledge. (Yogyakarta: Bentang Budaya, 2003), 3 
kepemimpinan, dan menjadi hegemonik, jika kelompok itu hanya membatasi pada kepentingan mereka sendiri; mereka harus memperhatikan tuntutan dan perjuangan rakyat yang tidak mempunyai karakter kelas yang bersifat murni, karena menjadi hegemonik dipahami dan dilihat sebagai upaya membangun aliansi secara menyeluruh, juga demi kepentingan perkembangan semua potensi nasional, ${ }^{20}$ sekaligus, tentu mengupayakan agar tuntutan rakyat tersebut bertemu dengan kepentingan mereka sendiri. "Hegemoni memerlukan penyatuan berbagai kekuatan sosial yang berbeda ke dalam sebuah aliansi yang luas yang mengungkapkan kehendak kolektif semua rakyat."21 Dengan demikan karena hegemoni dibentuk melalui kehendak kolektif masyarakat, ia dikatakan memiliki dimensi nasionalkerakyatan, di samping dimensi kelompok.

\section{c. Masyarakat Sipil (Civil Society) dan Kekuasaan}

Penggunaan istilah civil society, ditujukan oleh Gramsci sebagai revisi terhadap kebuntuan pandanganpandangan politik Marx dalam melihat perubahan struktur kelas yang terdapat di masyarakat dan menempati peran penting dalam melihat arah perubahan sosial ke depannya. Menurut Gramsci, tafsiran Marx tentang pertentangan kelas tidak sebatas terjelmakan dalam wilayah di mana

20 Antonio Gramsci. Selections from...h. 408

${ }^{21}$ Simon Roger, Gramsci's Political...h. 24

22 William K. Carrol, Studies In Social

Justice, Volume 1, issue 1 Winter 2007, 39

23 Isitilah 'masyarakat politik' tidak dimaksudkan untuk mengganti istilah 'negara', namun istilah ini hanya menunjuk pada hubungan-hubungan koersif yang terdapa pada aparat negara. Roger Simon, Gramsci's Political...h. 105. Bandingkan dengan Franz hubungan tuan-majikan berlangsung (baca: pabrik, atau bentuk lapangan kerja lainnya). Hegemoni tidak hanya terjadi di lingkup mikro.

Masyarakat sipil dalam pandangan Gramsci terdiri dari jaringan yang kompleks berbagai hubungan kekuatan sosial yang didominasi oleh konflik. ${ }^{22}$ Untuk itu ia membedakan antara masyarakat sipil dan masyarkat politik. Masyarakat politik adalah negara ditambah masyarakat sipil,23 yang menjalankan hegemoni dan dilindungi oleh tameng koersif. Sementara masyarakat sipil adalah sebuah hubungan sosial yang mencakup pribadi maupun organisasi-organisasi swasta, atau kelompok-kelompok masyarakat, yang berbeda dengan aparat negara.

Hubungan sosial yang membentuk masyarakat sipil berbeda dengan hubungan produksi, dan hubungan dalam masyarakat sipil berbeda dengan aparat-aparat yang membentuk Negara. $^{24}$ Masyarakat sipil adalah wadah perjuangan kelas dan perjuangan demokrasi kerakyatan. Jadi masyarakat sipil adalah wadah yang di situ kelompok sosial yang dominan mengatur konsensus dan hegemoni. Masyarakat sipil juga merupakan suatu wadah di mana kelompok-kelompok sosial yang lebih rendah (subordinate) dapat menyusun perlawanan mereka dan membangun sebuah hegemoni alternatif - hegemoni tandingan (counter hegemony). ${ }^{25}$

\footnotetext{
Magnis Suseno, Etika Politik : Prinsip-Prinsip Dasar Kenegaraan Modern. Jakarta : Gramedia. 1988, dan Stehanie Lawson, Some Conseptual and Empirical issues in the Study of Regime Change (Canberra : Departement of Political and Social Change, The Australian National University, 1991), 100 445-449

24 Antonio Gramsci, Selections from...h.

25 Roger Simon. Gramsci's Political...h. 27-
} 
Hubungan sosial dalam masyarakat sipil dalam pandangan Gramsci dipahami sebagai salah satu bentuk ataupun watak kekuasaan. Dalam hal ini kekuasaan itu adalah merata pada seluruh masyarakat sipil, bukan hanya milik aparat negara yang bersifat koersif. Ia menegaskan hal tersebut karena negara memiliki watak kekuasan yang ia sebut dengan hegemoni yang dilapisi dominasi kekuasaan. Secara sederhana pendapat tersebut ingin menjelaskan bahwa kekuasaan itu tidak selalu dianggap menguasai negara dan masyarakat sipil, tetapi kekuasaan itu bisa dianggap sebagai kepemimpinan suatu kelompok atas kelompok-kelompok lainnya dalam masyarakat sipil, bahkan kepemimpinan di dalam berbagai bidang lainnya.

\section{d. Commonsense dan Intelektual Organik}

Dalam beberapa catatannya yang tersebar dalam Selection from Prison Notebook, Gramsci memakai istilah commonsense (pemikiran orang awam) sebagai salah satu pelengkap teori hegemoni. Commonsense adalah orang yang tidak kritis dan tidak sadar dalam memahami dunia, cara mereka mempersepsi dunia, cara berfikir mereka seringkali rancu dan bertentangan, karena pemikiran mereka berasal dari berbagai sumber dan dari kejadian masa lalu, yang cenderung membuat mereka menerima ketidak adilan dan penindasan sebagai hal yang alamiah dan tidak dapat diubah. ${ }^{26}$

Ia tidak menafikan bahwa setiap orang sebenarnya adalah seorang

26 Simon Roger, Gramsci's Political...h. 27

27 Djohansyah Marzoeki, Budaya Ilmiah dan Filsafat Ilmu (Jakarta: Grsindo, 2000), 43, Yasraf Amir Piliang, Sebuah Dunia yang Dilipat (Jakarta: Mizan, 1998), 29

${ }^{28}$ Antonio Gramsci, Selection from.., 131 intelektual maupun filosof, tetapi tidak semua orang menjalankan fungsi intelektualnya di masyarakat. Mereka yang tidak bisa dan tidak mampu menjalankan fungsi tersebut disebut dengan commonsense. Pemikiran orang awam adalah tempat ditanamkan ideologi hegemonik, ${ }^{27}$ sekaligus tempat perlawanan terhadap ideologi itu sendiri, yang dilakukan secara tidak sadar karena pengaruh ekstrinsik maupun intrinsik.

Bagi mereka yang mampu dan memiliki ciri berfikir instrinsik serta menjalankan fungsinya di masyarakat ia sebut dengan intelektual organik. Kata Gramsci: "All men are potentially intellectuals in the sense of having an intellect and using it, but not all are intellectuals by social function." 28 Menurutnya intelektual adalah mereka yang memiliki fungsi sebagai organisator dalam semua lapisan masyarakat, politik, kebudayaan dan sebagainya.

Dari sini dia kemudian membedakan dua tipe intelektual yang ada dalam masyarakat. Yang pertama yaitu Intelektual Tradisional dimana intelektual ini terlihat independen, otonom, serta menjauhkan diri dari kehidupan masyarakat. Mereka hanya mengamati serta mempelajari kehidupan masyarakat dari kejauhan dan seringkali bersifat konservatif (anti terhadap perubahan). Contoh dari Intelektual Tradisional ini adalah para penulis sejarah, filsuf dan para profesor. Sedangkan yang kedua adalah Intelektual Organik, ${ }^{29}$ mereka adalah yang sebenarnya menanamkan ide, menjadi bagian dari penyebaran ide-ide

29 Masyarakat muslim sipil dengan ciriciri intelektual organik inilah yang disebut Muslim Abdurrahman dengan Muslim Civil Society Muslim Abdurrahman. Islam Sebagai Kritik Sosial (Jakarta: Paramadina, 2003),19-37 
yang ada di masyarakat dari kelas yang berkuasa, serta turut aktif dalam pembentukan masyarakat yang diinginkan.

\section{e. Ideologi}

Supremasi kelompok muncul dalam dua cara, yaitu dominasi (coersion) dan kepemiminan intelektual moral (hegemony). Kontrol sosial dilaksanakan dalam dua bentuk, mempengaruhi secara eksternal (dengan hukuman dan ganjaran), juga secara internal dengan membentuk keyakinan-keyakinan ideologis dalam norma yang berlaku. ${ }^{30}$

Istilah ideologi seringkali diartikan sebagai sebuah sistem ide. Bagi Gramsci ideologi lebih dari sekedar sistem ide. Ia membedakan antara sistem yang berubah-rubah (arbitrary systems) yang dikemukakan oleh intelektual dan filosof tertentu, dan ideologi organik yang bersifat historis (historically organic ideologies), yaitu ideologi yang diperlukan dalam kondisi sosial tertentu. ${ }^{31}$ Ideologi 'mengatur' manusia, dan memberikan tempat bagi manusia untuk bergerak, mendapatkan kesadaran akan posisi mereka, perjuangan mereka dan sebagainya. ${ }^{32}$

Ideologi bukanlah suatu yang berada di awang-awang, tetapi ada di dalam aktifitas politik dan praktis manusia. Ia memberikan aturan bagi tindakan praktis dan perilaku moral manusia, yang ekuivalen dengan agama. ${ }^{33}$ Oleh karena itu ideologi memiliki eksistensi material yang diartikan bahwa ideologi menjelma dalam praktik-praktik sosial setiap orang atau lembaga maupun organisasi. Tetapi ia tidak bisa direduksi hanya sebatas memiliki eksistensi material saja, tetapi ia juga ada dalam -dan terbentuk melalui- ide-ide,

30 Hendarto, Mengenal Konsep...h. 74-75, bandingkan dengan R. Kilminster, Praxis and Method: A Sosiological dialog with Lukacs, Gramsci, and Early Frankfurt School (London: Routledge \& Kegan Paul, 1979), 109-173

${ }^{31}$ Simon Roger...Gramsci’s Political ...h. 38 serta melalui hubungan antara konsep dan pernyataan.

Menurut Gramsci faktor terpenting sebagai pendorong terjadinya hegemoni adalah faktor ideologi dan politik (yang biasa diciptakan oleh penguasa) dalam mempengaruhi, mengarahkan, dan membentuk pola pikir masyarakat. Faktor lainnya adalah: 1) paksaan, sanksi yang diterapkan penguasa, hukuman yang menakutkan melalui peraturan-peraturan, 2) kebiasaan masyarakat dalam mengikuti suatu hal yang baru, seperti budaya baru, dan 3) kesadaran dan persetujuan dengan unsur-unsur yang ada dalam masyarakat $^{34}$ seperti indoktrinasi melalui lembaga pendidikan, agama dan lainnya.

Menurut Gramsci ada tiga fase perkembangan kesadaran ideologis:

1. Fase awal (disebut fase ekonomi korporasi), terjadi ketika seorang pedagang merasa perlu berdiri sejajar dengan pedagang lain, seorang pengusaha dengan pengusaha lain, dan sebagainya; namun pedagang belum merasakan timbulnya solidaritas dari pengusaha, sementara pengusaha belum menyadari kebutuhan untuk bergabung dengan kelompok lain dalam masalah yang sama.

2. Fase kedua, fase di mana telah tumbuh kesadaran akan kepentingan bersama semua kelas, namun masih dalam bidang tertentu, seperti hak memperoleh persamaan politik dan hukum dengan kelompok yang berkuasa, hak ikut serta dalam penetapan undang-

32 Antonio Gramsci. Selection from...h. 367

33 Ibid...h. 326

${ }^{34}$ Hendarto, Mengenal Konsep Hegemoni Gramsci,dalam Tim Redaksi Driyarkara, Diskursus Kemasyarakatan dan Kemanusiaan (Jakarta: Gramedia Pustaka, 1993), 73 
undang, namun tetap dalam struktur yang ada.

3. Fase ketiga adalah fase hegemoni, di mana orang menjadi sadar bahwa kepentingan kelasnya, melampaui batas-batas bidang tertentu, yang melampaui kepentingan kelompok lainnya yang sekelas atau yang lebih rendah. Ini adalah tahap murni politik. Ini adalah fase di mana ideologi-ideologi yang sebelumnya terpecah-pecah sekarang bersaing sampai salah satunya, atau gabungan dari ideologiideologi itu, menang dan menyatukan tujuan-tujuan bersama, serta mampu menghadapi semua persoalan. ${ }^{35}$

Gramsci memberikan tekanan pada peran perjuangan ideologis -pada reformasi intelektual moral- dalam mengubah pandangan semua kelompok, kerena ideologi berperan sebagai 'semen' atau kekuatan perekat (cohesive force) yang mengikat berbagai kelas/kelompok dan strata yang berbeda-beda.

Lebih dari itu Gramsci berpendapat bahwa ideologi, dalam hegemoni, tidak bisa dinilai dari apakah ia benar atau salah, tetapi harus dinilai dari 'kemanjurannya' dalam mengikat berbagai macam kelompok yang berbeda ke dalam satu wadah, karena fungsinya memang sebagai agen proses penyatuan sosial, pondasi atau kekuatan perekat hegemoni itu sendiri.

Oleh karena watak masyarakat yang cenderung lebih menerima ide-ide yang baik dan moralitas, maka kontinuitas ideologi pada dasarnya tergantung pada upaya mencari nilai positif. Dengan demikian hegemoni tidak berupaya membersihkan semua ideologi yang berbeda, tetapi melakukan transformasi terhadap ideologi-ideologi yang ada dengan tetap mempertahankan dan menyusun kembali unsur-unsur yang paling kuat menjadi sistem baru.

Salah satu watak material ideologi adalah bahwa praktik ideologi mempunyai agen-agen intelektualnya sendiri, yang bertugas menjabarkan ideologi-ideologi organik dan mengemban tugas melaksanakan reformasi moral dan intelektual. Oleh karena watak masyarakat yang cenderung lebih menerima ide-ide yang baik dan moralitas, maka kontinuitas ideologi pada dasarnya tergantung pada upaya mencari nilai positif. Dengan demikian hegemoni tidak berupaya membersihkan semua ideologi yang berbeda, tetapi melakukan transformasi terhadap ideologi-ideologi yang ada dengan tetap mempertahankan dan menyusun kembali unsur-unsur yang paling kuat menjadi sistem baru.

\section{f. Kontra Hegemoni/Hegemoni Tandingan (Counter Hegemony)}

Ideologi dalam teori hegemoni menjadi hal yang sentral karena ia merupakan instrumen utama dalam proses hegemoni. Oleh karena itu tugas menciptakan hegemoni baru (kontra hegemoni) hanya dapat diraih dengan mengubah kesadaran, pola berfikir, dan pemahaman masyarakat, konsepsi mereka tentang dunia, serta norma perilaku moral mereka. Indoktrinasi ideologi dalam hal ini sangat penting demi mempertahankan dominasi dan hegemoni oleh negara.

Civil society merupakan wilayah yang tidak dapat dengan begitu saja diinternalisasi oleh keberadaan atau pun campur tangan kekuatan maupun ideologi yang berskala lebih besar darinya (baca: negara). Civil society memuat dua kepentingan sosio-politis 
yang terbedakan melalui basis maupun kontrol yang dibangun atasnya. Di satu sisi, dengan menjejakan kekuataannya dalam civil society, negara dapat dengan mudah mengatur arah pergerakan kekuasaan yang sekiranya prospektif. Namun demikian, penguatan civil society, yang seringkali terpisah dan mengambil jarak spasial dengan sendirinya dari kebijakan dan percaturan politik yang digelar melalui kekuasaan negara, telah melahirkan arus perlawanan yang bergerak ke arah yang oposan. Ini terutama didukung dengan penambahan peran intelektual organik oleh Gramsci pada konsep civil society.

Masyarakat sipil, meski dengan watak awamnya, tidaklah selalu tertipu untuk selalu menerima dan mempercayai apa pun yang diberikan oleh kekuatan yang dominan. Terdapat contradictory consciousness ${ }^{36}$ (kesadaran berlawanan) dari masyarakat yang lebih menyadari akan kondisi hegemoni yang, sebenarnya, tidak mereka inginkan. Mereka mulai menolak indoktrinasi, menolak ide, mencoba membuat dan ide yang lebih baik, serta membangun aliansi konsensus yang berskala luas. Terkadang khalayak juga menggunakan sumber daya dan strategi yang sama seperti yang digunakan oleh kelompok sosial yang dominan. Hingga batasan tertentu, individu-individu akan menggunakan praktik-praktik dominasi hegemonis yang sama menentang dominasi yang ada,

${ }^{36}$ Antonio Gramsci. The Selections...h. 641

37 Istilah Gramsci krisis organik, yaitu krisis yang parah, yang permanen, yang telah terjadi selama beberapa puluh tahun yang kadang menuntut pembentukan ideologiideologi baru, sebagai bentuk dari upaya menciptakan keseimbangan baru dari krisis yang parah tersebut. . Lihat Antonio Gramsci, Selection From Prison Notebook. (Ed \& Terj) Quintin Hoare dan Geoffrey Nowell Smith penggunaan kekerasan, ancaman dan lain sebagainya. Inilah yang disebut Gramsci sebagai hegemoni tandingan atau kontra hegemoni (counter hegemony).

Hegemoni

tandingan memungkinkan, baik bagi setiap individu atau pun kelompok yang terepresi, untuk mencipta dan memperbaharui sejarah serta arah pertumbuhan sosial sebagai kepentingan maupun keperluan yang sifatnya komunal, selain menyertakan ruang kebebasan atau subjektivitas individu ke

dalam kesepakatan atau rumusan politiknya. Re-organisasi ide dan tujuan bersama ini merupakan hal pokok dalam menjalankan program-program perbaikan tersebut. Apa yang selebihnya di tata ulang adalah penempatan budaya serta nilai-nilai kemasyarakatan suatu kelompok masyarakat yang selama ini tersebar di beberapa wilayah sosial namun tak mendapatkan tempat yang seharusnnya.

Sementara itu, pada sisi lain, hegemoni negara tidak selamanya bertahan, ia sekali-kali akan goyah, mengalami krisis ${ }^{37}$ dan ketidak stabilan ketika ide-ide kebijakan pemerintah tidak sejalan dengan kehendak masyarakat, di mana kehidupan negara merupakan "suatu proses pembentukan dan penggantian yang terus berlangsung akan keseimbangan yang tidak stabil."38 Dengan kata lain kehidupan negara memiliki otonomi relatif39 karena ia adalah hasil dari

(London: Lawrence \& Wishart. 1971), 181-182 dan 400. Lihat juga Roger Simon. Gramsci's Political ..., 42 dan 110-111, Xavier Bonal, The Neoliberal Educational Agenda and The Legitimation Crisis: Old and New State Strategies, dalam British Journal of Sociology of Education, Vol. 24, no. 2, 2003, 162

38 Roger Simon. Gramsci's Political...h.100

39 John Gray, Kekuasaan Politik, Teori Sosial dan Pertaruhan Nilai-nilai. Dalam 
keseimbangan berbagai kekuatan, yang menjadikannya hegemonik. Kata Gramsci: "In the East the State was everything, civil society was primordial and gelatinous; in the West, there was a proper relation between State and civil society, and when the State trembled a sturdy structure of civil society was at once revealed." (Di Timur, negara adalah segalanya, masyarakat sipil adalah primordial dan lemah; di Barat, terdapat hubungan yang serasi antara negara dan masyarakat sipil, dan ketika negara mengalami kegoncangan maka struktur masyarkat sipil segera menggantikannya) 40

Ketidakseimbangan hegemoni politik pada waktunya melahirkaan orang-orang yang memiliki kesadaran intelektual organik, dan bergerak ke arah gerakan sosial ${ }^{41}$ politis maupun non politis.. Gerakan sosial tersebut lahir sebagai reaksi suatu kelompok atas ketidakpuasan mengenai keadaan tertentu, yang dilihat, disadari dan dipahami oleh para intelektual, yang kadang menciptakan organisasi permanen, serta berkehendak untuk memperkuat kembali batas-batas hegemoni maupun kontra hegemoni. ${ }^{42}$ Hingga batasan tertentu, individuindividu akan menggunakan praktik-

Fakhruddin R. Lubis, dkk (terj) Politik dalam Perspektif Pemikiran, Filsafat dan Teori (Jakarta: Rajawali, 1986), 124

${ }^{40}$ Antonio Gramsci, Selection From,..., 494

41 Gerakan sosial adalah salah satu bentuk dari perilaku kolektif. Secara formal gerakan sosial didefinisikan sebagai suatu gerakan kolektif dengan kadar kesinambungan tertentu untuk menunjang atau menolak perubahan yang terjadi dalam masyarakat atau kelompok tertentu. Paul B. Horton dan Chester L. Hunt. Sosiology, Syxth Edition. (Ter) Aminuddin Ram. (Jakarta: Erlanngga, 1984) 195

42 Margareth M. Poloma, Sosiologi Kontemporer. (Ter) Tim Yasogama, (Jakarta: 2007), 107

43 Diskusi mengenai hal POS ini dapat dibaca dalam Doug McAdam, Sydney Tarrow \& praktik dominasi hegemonis yang sama menentang dominasi yang ada. Inilah yang disebut Gramsci sebagai hegemoni tandingan (counter-hegemony).

Gerakan sosial semacam itu biasanya muncul dalam mekanisme Political Opportunity Structure (POS) ${ }^{43}$ seperti yang disampaikan Peter Eisinger, yaitu: pertama, gerakan sosial muncul ketika tingkat akses terhadap lembaga-lembaga politik mengalami keterbukaan; kedua, ketika keseimbangan politik baru belum terbentuk; ketiga, ketika para elite politik mengalami konflik besar dan konflik ini dipergunakan oleh para pelaku perubahan sebagai kesempatan; keempat, ketika para pelaku perubahan digandeng oleh para elite yanng berada di dalam siste untuk melakukan perubahan. ${ }^{44}$

Oleh karena itu ketika akan melakukan Counter Hegemoni para pelaku perubahan (kaum intelektual organik) haruslah berangkat dari kenyataan yang ada di masyarakat, ${ }^{45}$ mereka haruslah orang yang berpartisipasi aktif dalam kehidupan masyarakat, menanamkan kesadaran baru yang menyingkap kebobrokan sistem lama dan dapat mengorganisir masyarakat, dengan

Charles Tilly, Dynamics of Contention, (Cambridge: Cambridge University Press, 2001), 14, Jackie Smith, Ron Pagnucco \& Charles Chatfield, Social Movements and World Politics: A Theoritical Framework, dalam Transnational Social Movements and Global Politics Solidarity Beyond The State, (ed) Jackie Smith, Ron Pagnucco \& Charles Chatfield, (New York: Syracuse University, 1997), 66

44 Peter Eisinger, American Political Science Review, dalam Abdul Wahib Situmorang, Gerakan Sosial Studi Kasus Beberapa Perlawanan, Yogyakarta: Pustaka Pelajar, 2007, 4

45 Anne Showstack Sassoon, Gramsci and The Comtemporary Politic, Beyond Pessimism of The Intelect, (London: Routledge, 2000), 79 
begitu ide tentang pemberontakan serta merta dapat diterima oleh masyarakat hingga tercapainya apa yang biasa disebut revolusi.

Hegemoni tandingan menjadi bagian penting dalam pemikiran kajian budaya karena hal ini menunjukkan bahwa khalayak tidak selamanya akan menurut. Dengan kata lain, kita sebagai khalayak tidak selamanya bodoh dan pasif. Pesanpesan hegemoni tandingan, ironisnya, sering muncul juga di dalam programprogram televisi yang sifatnya mengkritisi atau pelencengan makna pesan yang sebenarnya, seperti program acara televisi 'Democrazy", "Sentilan-Sentilun", dan lainnya .

Tidak ada pesan hegemoni atau hegemoni tandingan yang dapat muncul tanpa kemampuan khalayak untuk menerima pesan dan membandingkannya dengan makna yang telah tersimpan di dalam benak mereka. Hal ini disebut pengkodean (decoding). Ketika kita menerima pesan dari orang lain, kita mendekodekan pesan-pesan tersebut berdasarkan persepsi, pemikiran, dan pengalaman masa lalu kita. Selain itu perbedaan dalam pendekodean terhadap pesanpesan dari kelas yang berkuasa juga disebabkan oleh ketidakmerataan hubungan sosial antara atasan dan bawahan, antara aparat negara dengan masyarakat sipil.

Masyarakat

melakukan pendekodean terhadap pesan melalui tiga sudut pandang atau posisi: dominan-hegemonis, ternegosiasi, dan oposisi. Ketika setiap individu bekerja di dalam sebuah kode yang mendominasi dan menjalankan kekuasaan yang lebih besar daripada yang lainnya, masyarakat cenderung menerima pesan secara pasif, menerima apa adanya. Posisi kedua adalah posisi ternegosiasi;

46 Antonio Gramsci, The Selections.., 495, bandingkan dengan Dominic Strinati, An anggota khalayak dapat menerima ideologi dominan tetapi akan bekerja dengan beberapa pengecualian terhadap aturan budaya. Dalam hal ini, anggota khalayak selalu memiliki hak untuk menerapkan kondisi lokal kepada peristiwa sekala besar. Dalam posisi ini, khalayak memaknai pesan dengan menegosiasikan pada konteks-konteks tertentu, apakah menerima atau menolak pesannya.

Cara terakhir yang digunakan khalayak untuk melakukan pendekodean terhadap pesan adalah dengan telibat di dalam posisi oposisional. Posisi oposisional terjadi ketika anggota khalayak mensubstitusikan kode alternatif bagi kode yang disediakan oleh media. Oleh karena itu, pada kasus ini konsumen yang kritis akan menolak makna sebuah pesan yang dipilih dan ditentukan oleh media dan menggantikannya dengan pemikirannya sendiri mengenai subjek tertentu.

Agar kaum buruh dapat menciptakan hegemoninya, Gramsci memberikan 2 cara ${ }^{46}$, yaitu melalui 'war of position' (perang posisi) dan 'war of movement' (perang pergerakan). Perang posisi dilakukan dengan cara memperoleh dukungan melalui propaganda media massa, membangun aliansi strategis dengan barisan sakit hati, pendidikan pembebasan melalui sekolah-sekolah yang meningkatkan kesadaran diri dan sosial. Karakteristiknya:
a. Perjuangan panjang
b. Mengutamakan perjuangan dalam system
c. Perjuangan diarahkan kepada dominasi budaya dan ideology

Perang pergerakan juga bisa dilakukan dengan serangan langsung (frontal), tentunya dengan dukungan

Introduction to ...h. 124, dan Roger Simon, Gramsci's Political...h. 110 
massa. Perang pergerakan bisa dilakukan setelah perang posisi dilakukan, bisa juga tidak.

\section{Metode}

Berdasar pada tipe pembahasan tulisan ini, maka metode yang digunakan adalah library research karena mencoba memahami konsepkonsep realitas menggunakan literatur (kepustakaan), baik berupa buku, jurnal maupun laporan.

Sementara

analisisnya menggunakan analisis kritis yang fleksibel. Teori Hegemoni Gramsci secara keseluruhan digunakan untuk membedah pesantren dalam bayangan hegemoni sekaligus kontra hegemi terutama dalam konteks kebijakan pendidikan keagamaan Islam di Indonesia.

\section{Hegemoni dan Kontra Hegemoni dalam Kebijakan Pendidikan Keagamaan Islam (Kasus Pesantren Mu'adalah)}

Selama beberapa dekade perhatian dan pengakuan (recognition) pemerintah terhadap institusi pesantren khususnya yang tidak menyelenggarakan pendidikan Madrasah/Sekolah formal masih sangat minim, ${ }^{47}$ bahkan tamatan Persantren yang belum mendapat pengakuan mu'adalah/kesetaraan sering menemui kesulitan untuk melanjutkan belajar ke jenjang pendidikan yang lebih tinggi maupun untuk melamar pekerjaan pada

47 Standar ganda dalam sistem pendidikan di Indonesia yang dimulai sejak pemerintahan orde lama pun justru tidak memberikan ruang pada pendidikan pesantren yang termarjinalkan. Lihat Muhammad Sirozi. Politik Kebijakan Pendidikan di Indonesia: Peran Tokoh-tokoh Islam dalam penyusunan UU $n$. 2/1989, Jakarta: INIS, 2004, 39-46. Bandingkan dengan Florian Pohl. Islamic Education And The Public Sphere Today's Pesantren in Indonesia. Munster: Waxman Verlag GmbH, 2009, 85-87 sektor formal. Sementara itu, masyarakat telah memberikan pengakuan terhadap kualitas lulusan Pesantren, dan bahkan sebagian dari lembaga pendidikan di luar negeri pun telah memberikan pengakuan kesetaraan (mu'adalah) terhadap pendidikan di pondok pesantren. Kondisi tersebut kemudian memunculkan beberapa tokoh pesantren sebagai intelektual organik yang mendesak pemerintah untuk memberikan pengakuan kesetaraan (mu'adalah) ${ }^{48}$ bagi mereka yang sistem maupun kurikulum pendidikannya tidak mengikuti aturan departemen pendidikan nasional ataupun kementerian agama, tetapi dikelola dengan kualitas pendidikan yang baik sesuai dengan nilai-nilai agama maupun nilai budaya lokal-nasional.

Dalam melanggengkan hegemoni ideologisnya, pemerintah berupaya memberikan pengakuan penyetaraan (mu'adalah) sejak tahun 1998, di mana pesantren diberi akses untuk memperoleh fasilitas yang sama seperti institusi-institusi pendidikan lainnya manakala mengikuti regulasi-regulasi yang telah ditetapkan pemerintah. Kemudian berdasarkan pada UndangUndang Sisdiknas nomor 20 tahun 2003 pasal 30 ayat 3,dan 4 serta Peraturan Pemerintah (PP) tentang Standar Nasional Pendidikan (SNP) nomor 19 tahun 2005 pasal 93, yang dilanjutkan dengan lahirnya PP 55 Tahun 2007, Peraturan Menteri Agama (PMA) No. 2

48 Pondok Pesantren Mu`adalah adalah pondok pesantren yang disetarakan dengan SMA / MA. Lihat Asrori S. Karni. Etos Studi Kaum Santri, Wajah Baru Pendidikan Islam, Jakarta: Mizan, 2009, 188.. Lihat juga Kementerian Agama RI. 2010. Pedoman Pesantren...h. 3, bandingkan dengan Umar Bukhory, Status Pesantren Muadalah; Antara Pembebasan dan Pengebirian Jati Diri Pendidikan Pesantren, dalam KARSA Jurnal Ilmiah vol IXI no. 1 April 2011, 57 
tahun 2012 yang direvisi dengan PMA No. 31 tahun 2013 serta direvisi kembali dengan PMA No. 18 tahun 2014 Tentang Satuan Pendidikan Muadalah pada Pondok Pesantren, Guru-guru dari pesantren mu`adalah mendapatkan hak yang sama seperti guru-guru dari sekolah swasta, seperti dapat mengikuti sertifikasi guru, impassing dan lainnya. ${ }^{49}$

Munculnya kebijakan pemerintah yang bersikap fleksibel dalam rekognisi formal sistem pendidikan pesantren secara formal tidak dapat dilepaskan dari upaya elit pesantren muadalah dalam memperjuangkan kebijakan yang memihak sejak tahun 1998 yang diinisiasi Pondok Modern Gontor bersama pesantren lainnya. Mereka kemudian membentuk forum komunikasi yang dikenal dengan Forum Komunikasi Pesantren Mu'adalah (FKPM) yang diketuai oleh Dr. K.H. Amal Fathullah Zarkasyi, M.A.

Melalui forum tersebut pesantren mu'adalah terus memberikan masukanmasukan bagi pemerintah dalam hal kebijakan-kebijakan strategis terkait dengan pengembangan dan perkembangan pesantren ke depannya. Salah satu polemik yang sempat didiskusikan secara cukup alot adalah upaya pemerintah dalam menskenariokan pesantren untuk dimasukkan ke dalam wilayah pendidikan formal hingga terbitnya Peraturan Menteri Agama (PMA) no. 3 tahun 2012 yang memang sejak awal atas usulan FKPM.

Sudah sejak awal tahun 2008 rancangan PMA tersebut dikaji dan didiskusikan diberbagai pertemuan. Diskusi yang terjadi dikalangan pejabat Kementerian Agama Pusat, anggota DPR, para akademisi, tokoh masyarakat, dan para pimpinan pondok pesantren terkait dengan penerbitan PMA. Silang pendapat pro dan kontra begitu hangat muncul dalam setiap diskusi/pertemuan yang membahas hal tersebut. Semua pihak menyadari sepenuhnya tentang betapa pentingnya sebuah PMA dan skenario baru tersebut, tetapi para pimpinan pondok pesantren tidak menghendaki ada pesantren yang dikorbankan atau pembiasan sistem pendidikan pesantren. Para kiai pimpinan pesantren tidak ingin terpecah konsentrasinya dengan kesibukan mencari pengakuan legal formal untuk para santrinya dengan mendirikan sekolah umum/formal yang terkadang, tanpa disadari, justru akan membelokkan arah pesantren dari semangat tafaqquh fiddin. Kekhawatiran tersebut bukan tanpa alasan karena bukti faktual di lapangan menunjukkan kalau belakangan ini muncul fenomena yang patut disikapi dengan cermat dan kritis, yaitu ramainya pendirian sekolah-sekolah umum keagamaan di lingkungan pesantren maupun diluarnya.

Untuk itu FKPM telah memberikan koreksian atau masukan terhadap draf Rancangan Peraturan Menteri Agama (RPMA) karena ditemukan indikasi materi peraturan yang lebih rendah bertentangan dengan materi peraturan yang lebih tinggi. Adapun hal yang diajukan FKPM tersebut sesuai dengan UU No. 20 Tahun 2003 tentang Sisdiknas, pada pasal 30 ayat 4 yang secara tegas menyatakan adanya pemisahan antara pendidikan pesantren dan pendidikan diniyah. Selain itu, dalam Peraturan Pemerintah (PP) No. 55 Tahun 2007 tentang Pendidikan Agama dan Pendidikan

49 Lihat Keputusan Direktur Jendral Pendidikan Islam nomor Dj.I/885/2010. 
Keagamaan serta PP No. 19 Tahun 2005 tentang Standar Nasional Pendidikan juga menyatakan hal yang sama. Dengan hadirnya peraturan tersebut pesantren berharap akan bisa lebih fokus lagi dalam mengembangkan pendidikan pesantren di masa mendatang, dapat diakui oleh pemerintah secara formal, dibantu baik secara finansial maupun lainnya, diakomodasi segala keperluan dan kepentingan nilai-nilai baiknya sehingga mampu melahirkan generasi ulama intelek, yang menguasai ilmuilmu keagamaan sekaligus ilmu sosial dan alam dengan cara maupun sistem yang khas pesantren.

Selain itu terkait dengan adanya keputusan sepihak dari sejumlah perguruan tinggi negeri yang tidak menerima alumni pesantren mu'adalah untuk mengikuti Seleksi Nasional Masuk Perguruan Tinggi Negeri (SNMPTN) disebabkan tidak adanya hasil Ujian Nasional (UN) pada nilai kelulusan mereka. Maka, FKPM sepakat menyampaikan usulan kepada Menteri Agama RI bahwa dalam penyusunan Permen tentang Pendidikan Pesantren agar tidak dimasukkan UN sejalan dengan PP 19 Tahun 2005 tentang SNP, pasal 93 ayat 1 dan 2 yang intinya tidak mengacu kepada SNP yang

50 Isi klausul yang ada, yaitu: 1) Penyelenggaraan satuan pendidikan yang tidak mengacu kepada Standar Nasional Pendidikan ini dapat memperoleh pengakuan dari Pemerintah atas dasar rekomendasi dari BSNP. 2) Rekomendasi dari BSNP sebagaimana dimaksud pada ayat (1) didasarkan pada penilaian khusus. 3) Pengakuan dari Pemerintah sebagaimana dimaksud pada ayat (1) ditetapkan dengan Peraturan Menteri. Lihat PP no. 19 tahun 2005 tentang Standar Nasional Pendidikan pasal 93

51 Keberatan pesantren muadalah terhadap UN bisa jadi karena standar penilaian UN tidak menjadikan kecerdasan lainnya sebagai penentu kelulusan seseorang, di mana pesantren dalam hal ini menjadikan nilai moralitas sebagai salah satunya. Lihat mengharuskan UN, $50 \quad$ walaupun demikian pesantren mu'adalah tetap mendapatkan pengakuan dari pemerintah atas dasar rekomendasi dari Badan Standar Nasional Pendidkan (BSNP) yang telah didapatkan pesantren mu'adalah tersebut. 51

Terkait Peraturan Menteri Agama (PMA) no 03 tahun 2012 tentang Pendidikan Keagamaan Islam, yang menurut beberapa anggota FKPM tergesa-gesa disyahkan, beberapa usulan telah dicantumkan, namun salah satu hal yang tetap menjadi polemik adalah FKPM menolak ketentuan dalam bab $\mathrm{V}$ pasal 43 tentang ketentuan peralihan yang menyatakan bahwa “ pesantren yang telah mendapatkan penyetaraan (muadalah) sebelum peraturan ini berlaku dinyatakan sebagai pendidikan diniyah formal berdasarkan peraturan ini" yang sudah tentu menggiring pesantren ke arah formalisasi pendidikan, kewajibannya untuk mengikuti Ujian Nasioanal dan merasa dipaksa untuk menjalankan sistem pendidikan yang tidak sejalan dengan sistem pendidikan asli (indegenousity) pesantren itu sendiri. 52 Sebagai konsekuensi logis dari hal itu ditakutkan pesantren tidak akan dapat berkembang secara wajar, ${ }^{53}$ kehilangan

Muhammad Rifai, Politik Pendidikan Nasional. Yogyakarta: Ar Ruzz, 2011, 194

52 Jika pesantren dipaksa untuk menjalankan sistem lain, suatu saat pesantren hanya akan tinggal nama seperti Taman Siswa, lihat Mohammad Idris Jauhari, Berharap Payung Hukum Muadalah dalam Ikhlas Beramal no. 57 Tahun XII Juni 2009, 50. Lihat juga Umar Bukhory, Status Pesantren Muadala..h. 56-57. Bandingkan dengan Makmuri Sukarno. Perguruan Taman Siswa: Kasus Pendidikan Berbasis Masyarakat Menghadapi Negara, dalam Masyarakat Indonesia, Majalah Ilmu-ilmu Sosial Indonesia, LIPI, Jilid XXX1V no. 2 2008,, 95-120

53 Moh. Hefni. Runtuhnya Hegemoni Negara dalam Menentukan Kurikulum Pesantren. dalam KARSA, Jurnal Ilmiyah. Vol. IXI no. 1 April 2011, 62 
jati dirinya yang asli, hanyut dalam sistem baru yang belum tentu lebih baik. Hasil diskusi panjang yang melibatkan berbagai macam kalangan hingga hearing dengan anggota DPR pada akhirnya melahirkan PMA No. 18 tahun 2014 hingga saat ini muncul Draft Rancangan Undang Undang Pendidikan Keagamaan Islam yang akan segera disahkan oleh pemerintah.

Deskripsi proses perjuangan pesantren mu'adalah dalam mendapatkan pengakuan pemerintah di atas merupakan bagian dari dinamika perkembangan pesantren di tanah air yang tidak bisa diremehkan. Perjuangan tersebut adalah bagian dari mempertahankan ciri, memantapkan watak dan prinsip kepesantrenan sebagai bentuk dari pelestarian keaslian atas kekuatan budaya bangsa dengan nilai-nilai luhur keagamaan ${ }^{54}$ atau dengan kata lain apa yang disebut Gramsci dengan counter culture atau counter hegemony terhadap hegemoni55 pemerintah dalam masalah pendidikan, maupun kehidupan umum masyarakat Indonesia yang sedang dilanda krisis moral,56 atau juga sebuah upaya mempertahankan hegemoni pesantren mengenai ide dasar sistem pendidikan pesantren yang khas, dengan kata lain perjuangan itu adalah perang posisi ideologi mengenai sistem dan pelaksana sistem pendidikan itu sendiri.

\section{Penutup}

Pada dasarnya keputusan mengenai pendidikan pesantren yang

54 H.A.R Tilaar. Membenahi Pendidikan Nasional. Jakarta: Rineka Cipta, 2002,, 77-78

55 Istilah hegemoni dan counter hegemoni dari Gramsci bermakna dominasi oleh satu kelompok terhadap kelompok lainnya, dengan atau tanpa ancaman kekerasan, sehingga ide-ide yang didiktekan oleh kelompok dominan terhadap kelompok yang didominasi diterima sebagai sesuatu yang wajar (commonsense). Lihat Roger Simon. Gagasan- diatur dalam Peraturan Menteri Agama RI no 18 tahun 2014 ditujukan demi kepentingan dan kebaikan pesantren itu sendiri. Namun kita juga perlu menyadari bahwa sejarah memberikan fakta bahwa sistem pendidikan di negeri kita sejak awal menganut sistem pendidikan dikotomis antara warisan kolonial yang dinilai lebih modern dengan sistem yang distandarisasi. Berbeda dengan sistem pendidikan pesantren yang tidak memiliki standar dan memang sangat sulit menentukan standar pendidikan pesantren jika dilihat dari beragam tipologi pesantren yang tersebut di seluruh negeri ini. Implikasi logis dari hal itu membawa dampak pada kemarjinalan posisi pesantren dalam sistem pendidikan nasional.

Oleh karena itu PMA No. 18 tahun 2014 serta UU Pesantren selayaknya tidak telah terlalu jauh mengintervensi sistem pendidikan pesantren dengan keanekaragamannya sekaligus status indgenousity-nya. Kita perlu memahami bahwa masing-masing pesantren memiliki kekhususan tipikal yang berbeda satu sama lain. Ada pesantren yang hanya mengkhususkan pembelajaran Nahwu-Sharraf, Tafsir, Fiqih, kitab kuning, kajian Al-Qur'an dan sebagainya. Banyaknya tipe-tipe pesantren semacam itu menjadikan seorang santri tidaklah dipandang lengkap ilmunya serta kurang mendapatkan pengakuan sosial (social recognition), jika hanya belajar di pesantren tertentu, atau pada kiyai

gagasan Politik Gramsci, (terj) oleh Kamdani dan Imam Baihaqi, Yogyakarta: Insist. 2004, 19-32

56 Lihat, Azyumardi Azra, Esei-esei Intelektual Muslim Pendidikan \& Islam. Jakarta: Logos, 1999, 87. Lihat juga Syahrul A'dam. Pesantren: Kiai dan Tarekat (Satu Potret Sejarah Sosial Pendidikan Islam Indonesia) dalam Suwito (ed) Sejarah Sosial Pendidikan Islam. Jakarta: Kencana, cet. Ke 2 2008, 17 
tertentu. Faktor tersebut mendorong santri untuk melakukan perjalanan keilmuan (rihlah 'ilmiyyah) yang berguna tidak hanya untuk memperkaya ilmunya sendiri, namun juga pengalaman hidupnya, bahkan membuka ruang terjadinya pertukaran ilmu, di mana pada gilirannya, akan mendorong terjadinya pengayaan dunia keilmuan di lingkungan pesantren secara keseluruhan.

Kalangan pesantren menyadari hal itu sebagai sebuah upaya yang mengancam eksistensi pesantren dengan segala keunikannya. Upayaupaya pemerintah dalam menghegemoni sistem pendidikan nasional tampaknya masih akan terus mendapatkan pertentangan. Dari perspektif teori hegemoni dan kontra hegemoni yang diutarakan oleh Antonio Gramsci kita mencoba melihat dan memahami sisi lain dari kompleksitas politik dalam menghegemoni sistem pendidikan nasional melalui ide-ide dalam bentuk peraturan-peraturannya tersebut.

Dengan catatan sejarah yang panjang, pesantren merasa layak untuk memiliki sistem pendidikan yang sesuai dengan kekhasan dan keunikannya masing-masing. Kekhawatiran kalangan pesantren muadalah adalah bahwa kenyataan yang ada saat ini banyak pesantren lain yang menyelenggarakan sistem pendidikan modern, tetapi pesantren itu sebenarnya adalah jenis tersendiri. Jika pesantren dipaksa untuk menjalankan sistem lain, suatu saat pesantren hanya akan tinggal nama.

\section{Referensi}

A'dam, Syahrul. Pesantren: Kiai dan Tarekat (Satu Potret Sejarah Sosial Pendidikan Islam Indonesia) dalam Suwito (ed) Sejarah Sosial Pendidikan Islam. Jakarta: Kencana, cet. Ke 2, 2008
Abdullah, M. Amin, Pengajaran Kalam dan Teologi di Era Kemajemukan: Sebuah Tinjauan Materi dan Metode Pendidikan Agama, dalam Tashwirul Afkar, Edisi no. 11 tahun, 2001.

Abdurrahman, Muslim, Islam Sebagai Kritik Sosial. Jakarta: Paramadina, 2003

Asfar, Muhammad, Pergeseran Otoritas Kepemimpinan Politik Kiai, dalam Prisma, 5 Mei, 1995

Azra, Azyumardi, Esei-esei Intelektual Muslim Pendidikan \& Islam. Jakarta: Logos, 1999.

Bonal, Xavier. The Neoliberal Educational Agenda and The Legitimation Crisis: Old and New State Strategies, dalam British Journal of Sociology of Education, Vol. 24, no. 2, 2003.

Borg, Carmel, et.all. (ed) Gramsci and Education. Boston: Rowman \& Litlefield Publishers, 2002

Bruinessen, Martin Van, Kitab Kuning, Pesantren dan Tarekat: Tradisitradisi Islam di Indonesia. Jakarta: Mizan, 1995

Bukhory, Umar. Status Pesantren Muadalah; Antara Pembebasan dan Pengebirian Jati Diri Pendidikan Pesantren, dalam KARSA Jurnal Ilmiah vol IXI no. 1 April, 2011.

Carrol, William K. Studies In Social Justice, Volume 1, issue 1 Winter, 2007

Djauhari, Mohammad Tidjani. 2008, Masa Depan Pesantren Agenda yang belum Terselesaikan. Jakarta: Taj Publishing.

Eisinger, Peter. American Political Science Review, dalam Abdul Wahib Situmorang, Gerakan Sosial Studi Kasus Beberapa Perlawanan, Yogyakarta: Pustaka Pelajar, 2007 
Foucult, Michel. Power/Knowledge. Yogyakarta: Bentang Budaya, 2003,

Gilpin, Robert. A Realist Perspective on International Governance, dalam David Held, Anthony McGrew (ed), Governing Globalization, Cambridge: Polity Press, 2004

Gramsci, Antonio. Selection From Prison Notebook. (Ed \& Terj) Quintin Hoare dan Geoffrey Nowell Smith. London: Lawrence \& Wishart, 1971

Gray, John. Kekuasaan Politik, Teori Sosial dan Pertaruhan Nilai-nilai. dalam Fakhruddin R. Lubis, dkk (terj) Politik dalam Perspektif Pemikiran, Filsafat dan Teori, Jakarta: Rajawali, 1986

Halik, Fathol. Pendidikan Pesantren di Tengah Politisasi dan Globalisasi: Pesantren Madura Setelah Keruntuhan Orde Baru. Dalam KARSA Jurnal Ilmiah, Vol XV no. 1 April, 2009

Hefni, Moh. Runtuhnya Hegemoni Negara dalam Menentukan Kurikulum Pesantren, dalam KARSA, Jurnal Ilmiyah. Vol. IXI no. 1 April, 2011,

Hendarto, Mengenal Konsep Hegemoni Gramsci,dalam Tim Redaksi Driyarkara, Diskursus Kemasyarakatan dan Kemanusiaan. Jakarta: Gramedia Pustaka, 1993.

Horton, Paul B. dan Chester L. Hunt. Sosiology, Syxth Edition. (Ter) Aminuddin Ram. Jakarta: Erlanngga, 1984,

Ismail, Faisal. Percikan Pemikiran Islam, Yogyakarta : Bina Usaha, 1984

Jauhari, Mohammad Idris. Berharap Payung Hukum Muadalah dalam Ikhlas Beramal no. 57 Tahun XII Juni, 2009
Karni, Asrori S. Etos Studi Kaum Santri, Wajah Baru Pendidikan Islam, Jakarta: Mizan, 2009

Kementerian Agama RI. Pedoman Pesantren Muadalah. 2010

Keputusan Direktur Jendral Pendidikan Islam nomor Dj.I/885/2010.

Kilminster, R. Praxis and Method: A Sosiological dialog with Lukacs, Gramsci, and Early Frankfurt School, London: Routledge \& Kegan Paul, 1979,

Kuntowijoyo, Muslim Tanpa Masjid, Bandung: Mizan, 2001,

Kusmana dan JM. Muslimin, Paradigma Baru Pendidikan Retrospeksi dan Proyeksi Modernisasi Pendidikan Islam di Indonesia, Jakarta: IISEP, 2008

Lawson, Stehanie. Some Conseptual and Empirical issues in the Study of Regime Change. Canberra : Departement of Political and Social Change, The Australian National University, 1991

Madjid, Nurcholish. Bilik-Bilik Pesantren: Sebuah Potret Perjalanan, Cet. 1 Jakarta : Paramadina, 1997

Marzoeki, Djohansyah, Budaya Ilmiah dan Filsafat Ilmu, Jakarta: Grasindo, 2000

Mas'ud, Abdurrahman. Sejarah dan Budaya Pesantren. Dalam Ismail SM (ed) Dinamika Pesantren dan Madrasah. Yogyakarta: Pustaka Pelajar, 2002

Mas'ud, Abdurrahman. Format Baru Pola Pendidikan Keagamaan pada Masyarakat Multikultural dalam Perspektif Sisdiknas, dalam Muammar Ramadhan dan Hesti Hardinah (ed), Antologi Studi Agama dan Pendidikan, Semarang: Aneka Ilmu, 2004

Mastuhu. Dinamika Sistem Pendidikan Pesantren. Jakarta: INIS, 1994, 
Masyhud, Sulthon. Manajemen Pondok Pesantren. Jakarta: Diva Pustaka, 2003,

McAdam, Doug, Sydney Tarrow \& Charles Tilly, Dynamics of Contention, Cambridge: Cambridge University Press, 2001

Nata, Abuddin. Manajemen Pendidikan Mengatasi Kelemahan Pendidikan Islam di Indonesia. Jakarta: Kencana, 2003,

Peraturan Pemerintah no. 19 tahun 2005 tentang Standar Nasional Pendidikan

Piliang, Yasraf Amir. 1998, Sebuah Dunia yang Dilipat, Jakarta: Mizan

Pohl, Florian. Islamic Education And The Public Sphere Today's Pesantren in Indonesia. Munster: Waxman Verlag GmbH, 2009,

Poloma, Margareth M. 2007, Sosiologi Kontemporer. (Ter) Tim Yasogama, Jakarta:

Qomar, Mujammil, Pesantren Dari Transformasi Metodologi Menuju Demokrasi Institusi. Jakarta: Erlangga, 2006

Rifai, Muhammad. Politik Pendidikan Nasional. Yogyakarta: Ar Ruzz, 2011

Riyadi, Ali. Politik Pendidikan, Menggugat Birokrasi Pendidikan Nasional. Cet. 1 Yogyakarta: Ar Ruzz. 2006

Sassoon, Anne Showstack. Gramsci and The Comtemporary Politic, Beyond Pessimism of The Intelect, London: Routledge, 2000.

Simon, Roger. Gagasan-gagasan Politik Gramsci, (terj) oleh Kamdani dan Imam Baihaqi, Yogyakarta: Insist. 2004. Gramsci's Political Thought, an Introduction. London: Lawrence \& Wishart, 1982.

Sirozi, Muhammad. Politik Kebijakan Pendidikan di Indonesia: Peran
Tokoh-tokoh Islam dalam penyusunan UU n. 2/1989, Jakarta: INIS, 2004.

Smith, Jackie, Ron Pagnucco \& Charles Chatfield. Social Movements and World Politics: A Theoritical Framework, dalam Transnational Social Movements and Global Politics Solidarity Beyond The State, (ed) Jackie Smith, Ron Pagnucco \& Charles Chatfield, New York: Syracuse University, 1997.

Steenbrink, Kareel A. Madrasah, Pesantren, Sekolah: Pendidikan Islam dalam Kurun Modern. Jakarta: LP3ES. 1986,

Strinati, Dominic. An Introduction to Theories of Popular Culture, London: Routledge, 1995,

Sukarno, Makmuri. Perguruan Taman Siswa: Kasus Pendidikan Berbasis Masyarakat Menghadapi Negara, dalam Masyarakat Indonesia, Majalah Ilmu-ilmu Sosial Indonesia, LIPI, Jilid XXX1V no. 2, 2008

Suseno, Franz Magnis. Etika Politik :

Prinsip-Prinsip Dasar

Kenegaraan Modern. Jakarta :

Gramedia. 1988

Tebba, Sudirman. Dilema Pesantren: Belenggu Politik dan Pembaruan Sosial, dalam Dawam Raharjo (ed), Pergulatan Dunia Pesantren: Membangun dari Bawah, Jakarta: P3M, 1985

Tilaar, H.A.R. Membenahi Pendidikan Nasional. Jakarta: Rineka Cipta. 2002

Wahid, Abdurrahman, 2001, Menggerakkan Tradisi. Esai-esai Pesantren. Yogyakarta: LkiS

Bunga Rampai

Pesantren. Jakarta: Dharma Bhakti, 1984

Wahyuni, Akhtim. Peran Sosial Pesantren dalam Pemberdayaan 
masyarakat. Jurnal Ilmiah Kreatif, Vol. VI no. 1 Januari, 2009.

Williams, Raymond. Keywords: A Vocabulary of Culture and Society. Revised Edition, New York: Oxford University Press, 1985

Yamin, Moh. Menggugat Pendidikan Indonesia, Yogyakarta: Ar Ruzz Media, 2009. 